\title{
ACE inhibitors in cardiac surgery: current studies and controversies
}

\begin{abstract}
Jian-Zhong Sun ${ }^{1}$, Long-Hui Cao ${ }^{1,3}$ and Hong Liu $^{2}$
Major complications associated with cardiac surgery are still common and carry great prognostic significance. Current medical interventions to prevent these cardiovascular complications include antiplatelet therapy, statins, $\beta$-blockers and angiotensinconverting enzyme (ACE) inhibitors. Both experimental studies and clinical trials have shown that ACE inhibitors hold promise as cardiovascular protective agents for cardiac surgery patients. Several lines of evidence support this hypothesis. First, long-term use of ACE inhibitors has been well established to provide cardiovascular protection and reduce ischemic events and complications, independent of their effect on heart function and blood pressure. Second, early ACE inhibitor therapy has been demonstrated to produce remarkable survival and heart function benefits in patients with acute myocardial infarction. Third, ACE blockage can prevent or delay the development or progression of renal disease at all stages, from subclinical microalbuminuria to end-stage renal disease. Nevertheless, perioperative studies of the effects of ACE inhibitors remain few and inconclusive. Results from recent clinical trials and observational studies are conflicting and raise more questions than answers. Further studies, both retrospective and larger-scale prospective studies, are critically needed to examine whether ACE inhibitors reduce mortality and major complications in patients undergoing cardiac surgery.

Hypertension Research (2011) 34, 15-22; doi:10.1038/hr.2010.188; published online 14 October 2010
\end{abstract}

Keywords: ACE inhibitors; cardiac surgery; cardiovascular disease

\section{INTRODUCTION}

Cardiac surgery has experienced tremendous progress in the past four decades. As a result, open-heart surgery has become a common procedure today. Although there has been a significant decline in overall operative mortality for cardiac surgery, especially for coronary artery bypass grafts (CABG) (Table 1), major complications associated with cardiac surgery are still common and carry great prognostic significance. ${ }^{1-3}$ According to the Society of Thoracic Surgeons, the 30-day operative death and major complication rates for CABG procedures were 3.05 and $13.40 \%$, respectively, including stroke $(1.63 \%)$, renal failure (3.53\%), reoperation $(5.17 \%)$, prolonged ventilation $(5.96 \%)$ and sternal infection $(0.63 \%) .{ }^{4}$ Despite intensive studies, however, the mechanisms for cardiac surgery-associated major cardiovascular complications remain unclear and complex (Figure 1); in addition, clinical strategies to prevent these complications are few and unsatisfactory.

Current medical interventions to prevent these cardiovascular complications include antiplatelet therapy, ${ }^{5}$ statins, ${ }^{6} \quad \beta$-blockers ${ }^{7}$ and angiotensin-converting enzyme (ACE) inhibitors (Figure 1). For antihypertensive medications, in a large North American observational study ( $n=629866$ ), Ferguson et al found that preoperative $\beta$-blocker therapy was associated with a small but consistent survival benefit for patients undergoing CABG (unadjusted 30-day mortality,
2.8 vs. 3.4\%; odds ratio (OR), $0.80 ; 95 \%$ confidence interval (CI), $0.78-0.82) .^{7}$ This study suggests that preoperative $\beta$-blocker therapy may be beneficial for patients undergoing cardiac surgery. However, recent studies on perioperative $\beta$-blockers have created uncertainty and controversy (see Perioperative Ischemic Evaluation Study (POISE) trial $^{8}$ discussed below), indicating the need for further studies, especially for cardiac surgery patients. Meanwhile, there have been very few clinical studies on the effects of other antihypertensive medications in cardiac surgery patients. A few reports showed that these antihypertensive medicines had either no significant effect or a deleterious effect. ${ }^{9-11}$ For example, in a small randomized trial $(n=87)$, Flesch et al. reported that candesartan, an angiotensin II receptor blocker, did not affect postoperative cognitive or renal function in patients undergoing CABG. ${ }^{11}$ In a retrospective study ( $n=414$ ), Yong et al. reported that perioperative administration of intravenous diltiazem, a calcium-channel blocker, started after initiation of anesthesia and continued for $24 \mathrm{~h}$, was associated with increased renal dysfunction in patients undergoing cardiac surgery. ${ }^{9}$

In contrast, both experimental studies and clinical trials have shown that ACE inhibitors hold promise as cardiovascular protective agents for cardiac surgery patients. ${ }^{12}$ Thus, in this review, we will focus on ACE inhibitors, briefly review their research progress in cardiovascular diseases (CVD) in the non-surgical setting and then review in more

\footnotetext{
${ }^{1}$ Department of Anesthesiology, Thomas Jefferson University, Philadelphia, PA, USA and ${ }^{2}$ Department of Anesthesiology and Pain Medicine, University of California Davis Medical Center, Sacramento, CA, USA

${ }^{3}$ Current Address: Anesthesiology Department, State Key Laboratory in South China, Sun Yat-Sen University Cancer Center, 651 Dongfeng East Road, Guangzhou 510060, PR China. Correspondence: Dr J-Z Sun, Department of Anesthesiology, Thomas Jefferson University, 111 South 11th Street, Suite G8490, Philadelphia, PA 19107, USA. E-mail: jian-zhong.sun@jefferson.edu

Received 10 March 2010; revised 2 June 2010; accepted 1 July 2010; published online 14 October 2010
} 
Table 1 Abbreviations used in the text

\begin{tabular}{|c|c|}
\hline \multicolumn{2}{|l|}{ Medical terminology } \\
\hline ACE & Angiotensin converting enzyme \\
\hline AMI & Acute myocardial infarction \\
\hline ARB & Angiotensin II receptor blocker \\
\hline CABG & Coronary artery bypass graft \\
\hline $\mathrm{CHF}$ & Congestive heart failure \\
\hline $\mathrm{Cl}$ & Confidence interval \\
\hline CSA-AKI & Cardiac surgery associated-acute kidney injury \\
\hline CVD & Cardiovascular disease \\
\hline OR & Odds ratio \\
\hline RAS & Renin-angiotensin system \\
\hline RR & Relative risk \\
\hline \multicolumn{2}{|c|}{ Clinical trial acronym } \\
\hline APRES & $\begin{array}{l}\text { Angiotensin-converting Enzyme Inhibition Post } \\
\text { Revascularization trial }\end{array}$ \\
\hline BENEDICT & BErgamo NEphrologic Diabetes Complication trial \\
\hline BPLTTC & Blood Pressure Lowering Treatment Trialists' Collaboration \\
\hline CONSENSUS $॥$ & Cooperative New Scandinavian Enalapril Survival Study II \\
\hline EUROPA & $\begin{array}{l}\text { European Trial on Reduction of Cardiac Events with } \\
\text { Perindopril in Stable Coronary Artery Disease }\end{array}$ \\
\hline GISSI-3 & $\begin{array}{l}\text { Effects of lisinopril and transdermal glyceryl trinitrate singly } \\
\text { and together on } 6 \text {-week mortality and ventricular function } \\
\text { after acute myocardial infarction }\end{array}$ \\
\hline HOPE & Heart Outcomes Prevention Evaluation trial \\
\hline IMAGINE & $\begin{array}{l}\text { Ischemia Management with Accupril Post Bypass Graft via } \\
\text { Inhibition of Angiotensin Converting Enzyme trial }\end{array}$ \\
\hline POISE & Perioperative Ischemic Evaluation Study \\
\hline QUO VAIDS & $\begin{array}{l}\text { Effects of Quinapril on Clinical Outcome After Coronary } \\
\text { Artery Bypass Grafting }\end{array}$ \\
\hline SAVE & Survival and Ventricular Enlargement trial \\
\hline
\end{tabular}

detail the current studies of ACE inhibitors in cardiac surgery, especially the controversial findings. We will focus on major randomized clinical trials and also cover important observational cohort studies.

\section{MECHANISMS OF ACE INHIBITOR ACTION}

ACE has two primary functions. It catalyzes the conversion of angiotensin I to angiotensin II, a potent vasoconstrictor, and it is involved in the inactivation of bradykinin, a potent vasodilator. The effects of angiotensin II involve all organs and systems in vivo, including the heart, kidney, vessels, brain, the endocrine system, inflammation and cell growth. ${ }^{13}$ Blockage of the renin-angiotensin system (RAS) by ACE inhibitors results in decreased formation of angiotensin II, decreased inactivation of bradykinin, reduced secretion of aldosterone and vasopressin, decreased activity of the sympathetic nervous system and decreased trophic effects of angiotensin II. ${ }^{12,13}$

As illustrated in Figure 1, RAS is enhanced in cardiac surgery as a result of the extreme surgical stress and effects of extracorporeal circulation. ACE inhibitors can function on multiple sites and levels to block the stress response mediated by RAS and, thus, reduce potential ischemic events after cardiac surgery. The specific mechanism of ACE inhibitors in cardiac surgery needs further study. Nevertheless, as previous studies have shown, the cellular and molecular mechanisms responsible for ACE inhibitors' effects involve multiple factors, including the following:

(1) Minimization of thrombosis by reducing platelet aggregation and decreasing plasminogen activator- 1 and tissue plasminogen activator levels; ${ }^{14}$
(2) Preservation of endothelial function by preventing bradykinin breakdown, enhancing nitric oxide production and limiting vascular inflammation and oxidative stress; ${ }^{15}$

(3) Improvement of myocyte contractile function and prevention of non-myocyte cellular proliferation, collagen deposition and myocyte hypertrophic responses by normalization of $\beta$-adrenergic receptor function and enhanced myocardial collagen support; ${ }^{16}$

(4) Reduction of infarct size and left ventricular dilation by preservation of the left ventricular myocardial collagen matrix and reduction in the atrial natriuretic factor and cGMP, as well as preservation of sarcolemmal $\beta$-adrenergic receptor density and transduction; ${ }^{17}$

(5) Direct binding to matrix metalloproteinase-9, leading to inhibition of its activity, resulting in protection against ischemic heart disease. Matrix metalloproteinase- 9 is a $\mathrm{Zn}^{2+}$-dependent endopeptidase, and its activity is dramatically increased during the acute phase of myocardial infarction (MI). It has been suggested that matrix metalloproteinase- 9 has a crucial role in cardiac dysfunction and left ventricular dilatation. ${ }^{18,19}$ Selective matrix metalloproteinase inhibition reduces left ventricular remodeling but does not inhibit angiogenesis after $\mathrm{MI} ;{ }^{19}$

(6) Control of both systemic and glomerular capillary pressure, thereby improving glomerular permselectivity to proteins and reducing proteinuria; ${ }^{20}$

(7) Decreased production of many mediators of fibrosis, including transforming growth factor beta, fibronectin, laminin, endothelin and type-IV collagen. Apoptosis is also reduced, thereby attenuating glomerulosclerosis and tubulointerstitial fibrosis; ${ }^{20-23}$ and

(8) decreased activity of the central and peripheral sympathetic nervous systems by inhibition of norepinephrine release from the hypothalamus ${ }^{24}$ and by functioning through a bradykinin/ nitric oxide-mediated mechanism that stimulates the cGMP/ protein kinase $G$ signaling pathway. It also may participate in the potentiation of bradykinin release and kinin receptor expression, thereby reducing catecholamine-mediated surgical stress responses. ${ }^{25,26}$

Further studies are needed to define the role and significance of the above-mentioned experimental findings in real cardiac surgical patients.

\section{ACE INHIBITORS IN CVD}

The early developmental history of ACE inhibitors is only a prelude to their current broad applications in the treatment of cardiovascular disease, renal diseases and diabetes. In the 1980s and early 1990s, several major clinical studies clearly demonstrated that ACE inhibitors reduce cardiovascular mortality and morbidity in patients with heart failure or left ventricular systolic dysfunction. ${ }^{27-29}$

During the early and middle 1990s, investigators started to examine the effects of ACE inhibitor application in patients post-acute myocardial infarction (AMI). A series of clinical trials demonstrated the remarkable survival benefits of ACE inhibitors in patients with AMI. Specifically, a careful titration of ACE inhibitors in the immediate postinfarction period was applied in these trials to avoid the development of hypotension. ${ }^{30-33}$ For example, in the Survival and Ventricular Enlargement (SAVE) trial, ${ }^{33}$ within 3-16 days after MI, 2231 patients with ejection fractions $<40 \%$ but without overt heart failure or symptoms of myocardial ischemia were randomly assigned to receive either placebo (1116 patients) or captopril (1115 patients) 


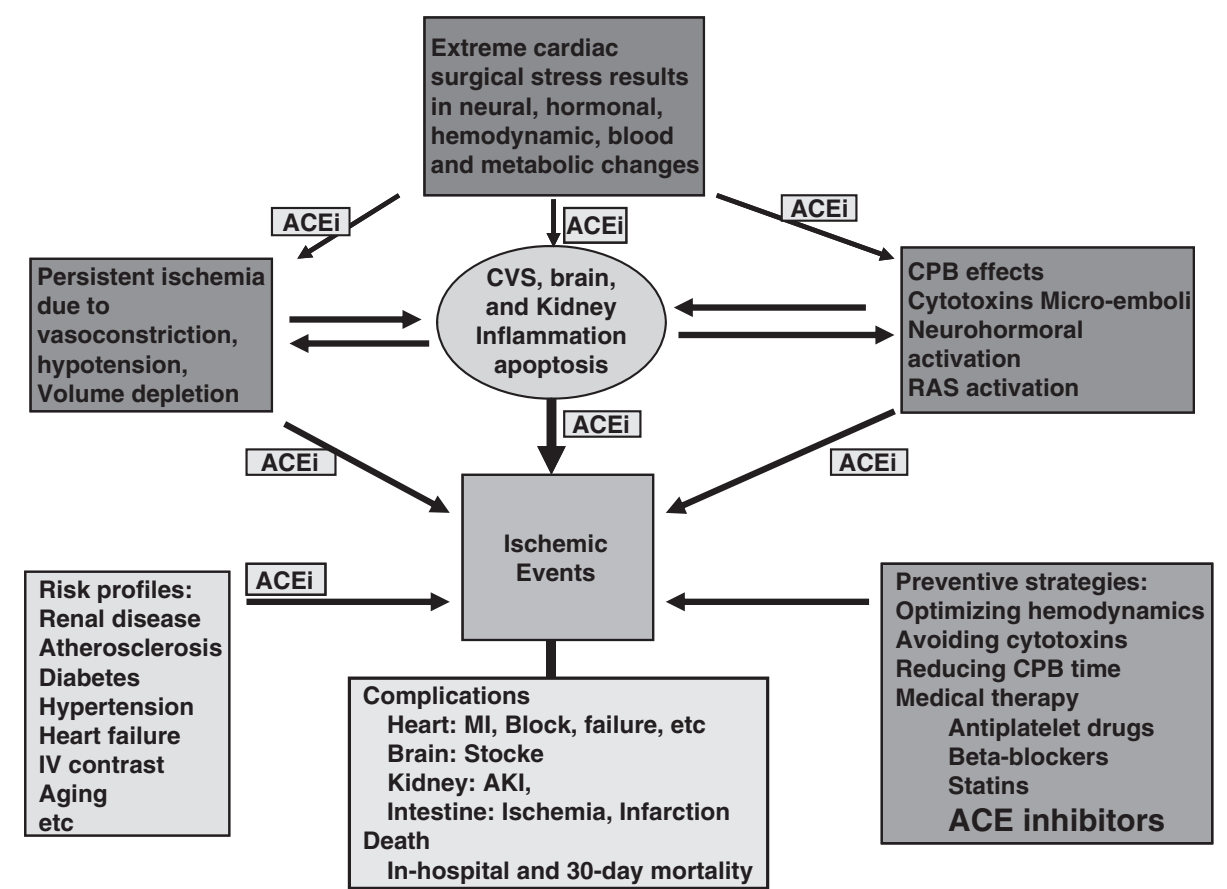

Figure 1 Proposed mechanisms for complications of cardiac surgery and actions of ACEi blockade on multiple sites and levels. ACEi, angiotensin-converting enzyme inhibitor; AKI, acute kidney injury; CPB, cardiac pulmonary bypass; CVS, cardiovascular system; MI, myocardial infarction.

and were followed up for an average of 42 months. The results showed that all-cause mortality was significantly reduced in the captopril group (228 deaths, or 20\%) compared with the placebo group (275 deaths, or $25 \%$ ); the reduction in risk was $19 \%$ (95\% CI 3-32\%; $P=0.019)$. In addition, the incidence of both fatal and non-fatal major cardiovascular events was consistently reduced in the captopril group. The risk reduction was $21 \%(95 \% \mathrm{CI}, 5-35 \% ; P=0.014)$ for death from cardiovascular causes, $37 \%$ (95\% CI, 20-50\%; $P<0.001)$ for the development of severe heart failure, $22 \%$ (95\% CI, $4-37 \% ; P=0.019)$ for congestive heart failure ( $\mathrm{CHF}$ ) requiring hospitalization and $25 \%$ (95\% CI, 5-40\%; $P=0.015$ ) for recurring MIs.

In the early 2000s, increasing evidence showed that ACE inhibitors also provide end-organ protection, independent from their effects on ventricular function and blood pressure. Two large randomized clinical trials, the Heart Outcomes Prevention Evaluation (HOPE) trial $^{34}$ and the European Trial on Reduction of Cardiac Events with Perindopril in Stable Coronary Artery Disease (EUROPA), ${ }^{35}$ demonstrated that ACE inhibitors could affect the atherosclerotic process and reduce ischemic events and complications independent of their effects on heart function and blood pressure. For example, in the HOPE study, ${ }^{34}$ patients at high risk for cardiovascular events but without left ventricular dysfunction or heart failure received ramipril ( $10 \mathrm{mg}$ once daily) or placebo. After a mean follow-up of 5 years, treatment with ramipril reduced the rates of death from cardiovascular causes $(6.1 \%$ in the ramipril group vs. $8.1 \%$ in the placebo group; relative risk (RR) $0.74 ; P<0.001$ ), MI (9.9 vs. $12.3 \%$; RR 0.80 ; $P<0.001)$, stroke (3.4 vs. 4.9\%; RR 0.68; $P<0.001)$, death from any cause (10.4 vs. $12.2 \%$; RR $0.84 ; P=0.005)$, revascularization procedures $(16.3$ vs. $18.8 \%$; RR $0.85 ; P<0.001)$, cardiac arrest $(0.8$ vs. $1.3 \%$; RR 0.62; $P=0.02)$, (corrected) heart failure (9.1 vs. $11.6 \%$; RR 0.77 ; $P<0.001)$ and complications related to diabetes $(6.4$ vs. $7.6 \%$; RR $0.84 ; P=0.03)$.
In the Blood Pressure Lowering Treatment Trialists' Collaboration (BPLTTC, a meta-analysis from 26 large-scale trials), in terms of blood pressure-dependent effects, ACE inhibitors and angiotensin II receptor blockers showed similar magnitudes of risk reduction for stroke, coronary artery disease and heart failure. With regard to blood pressure-independent effects, however, at zero blood pressure reduction, ACE inhibitors were associated with a significantly decreased risk of coronary artery disease. This cardioprotective effect of ACE inhibitors was significantly greater than that of angiotensin II receptor blockers, a similar drug class. ${ }^{36}$

Recently, multiple clinical trials and meta-analyses of these trials led to the conclusion that ACE inhibitors reduce total mortality and major cardiovascular events in patients with coronary artery disease without left ventricular systolic dysfunction or heart failure. ${ }^{37,38}$ As clearly stated in an expert consensus document on ACE inhibitors in CVD issued by the European Society of Cardiology in 2004, 'longterm treatment with ACE inhibitors in patients without heart failure is beneficial in patients with known CVD or diabetes and some other risk factors. ${ }^{39}$ This recommendation was labeled as class I, level of evidence $\mathrm{A}$.

\section{ACE INHIBITORS IN RENAL DISEASE}

Another unique feature of ACE inhibitors is their renoprotective effect. Several major randomized clinical trials with ACE inhibitors have clearly demonstrated that ACE blockage can prevent or delay the development or progression of renal disease at all stages of the continuum, from subclinical microalbuminuria to end-stage renal disease. ${ }^{40-44}$ In the BErgamo NEphrologic DIabetes Complication (BENEDICT) trial (2004), Ruggenenti et al. investigated the effect of the ACE inhibitor trandolapril in 1204 hypertensive patients with type 2 diabetes and normal urinary albumin excretion. After a median of 3.6 years of follow-up, microalbuminuria had developed in $11 \%$ of the 
placebo group and in $6 \%$ of patients who received ACE inhibitor therapy. After adjustment for baseline variables, the acceleration factor (a measure of the effect of one treatment relative to another on the progression of disease) was 0.44 in the ACE inhibitor group compared with the placebo group, indicating that ACE inhibitor therapy significantly delayed the progression of renal impairment. ${ }^{44}$

\section{ACE INHIBITORS IN CARDIAC SURGERY}

Table 2 lists major clinical studies on ACE inhibitors in cardiac surgery, and both randomized clinical trials and observational studies are covered, with emphasis on randomized trials.
Effects of ACE inhibitors on major morbidity and mortality in cardiac surgery

In the late 1990s, (Table 2) a few observational studies by Rady et al. ${ }^{45}$ and Weightman et al. ${ }^{46}$ showed that preoperative therapy with ACE inhibitors did not have a significant effect on clinical outcomes after cardiac surgery, including organ dysfunction, duration of mechanical ventilation, length of stay in ICU or in-hospital mortality.

In 2001, Oosterga et al., ${ }^{47}$ in the Effects of Quinapril on Clinical Outcome After Coronary Artery Bypass Grafting (QUO VAIDS) trial, examined whether quinapril, an ACE inhibitor, can decrease ischemic events, including death, revascularization, MI, recurrence of angina

Table 2 ACE inhibitors in cardiac surgery: major clinical studies

\begin{tabular}{|c|c|c|c|c|c|c|}
\hline Study & Design & $\begin{array}{l}\text { Groups and patient } \\
\text { numbers }\end{array}$ & Morbidity (\%) & $\begin{array}{l}\text { Mortality } \\
\text { (\%) }\end{array}$ & $\begin{array}{l}R R, H R \text { or } O R \\
(95 \% \mathrm{Cl})\end{array}$ & Comments \\
\hline $\begin{array}{l}\text { QUO VAIDS } 47 \\
2001\end{array}$ & RCT & $\begin{array}{l}\text { Quinapril, } n=75 \\
\text { Placebo, } n=73\end{array}$ & $\begin{array}{l}\text { Ischemic events }{ }^{b} \\
4^{a} \\
15 \\
\text { Composite results }^{c}\end{array}$ & NA & $\begin{array}{l}\text { ACEi vs. placebo: HR } 0.23 \\
(0.06-0.87)\end{array}$ & $\begin{array}{l}\text { Quinapril } 40 \mathrm{mg} / \text { day started } 4 \text { weeks } \\
\text { before CABG and continued for one year. }\end{array}$ \\
\hline $\begin{array}{l}\text { APRES } 48 \\
2000\end{array}$ & $\mathrm{RCT}$ & $\begin{array}{l}\text { Ramipril, } n=80 \\
\text { Placebo, } n=79\end{array}$ & $\begin{array}{l}8^{a} \\
18\end{array}$ & $\begin{array}{l}1^{a} \\
7\end{array}$ & $\begin{array}{l}\text { ACEi vs. placebo: RR } 0.58 \\
\text { (7-80) for composite results }\end{array}$ & $\begin{array}{l}159 \text { patients ( } 130 \text { CABG, } 29 \mathrm{PCI} \text { ) with } \\
\text { moderately depressed ejection fraction } \\
\text { received ramipril or placebo for a med- } \\
\text { ian } 33 \text { months. }\end{array}$ \\
\hline HOPE $^{34} 2000$ & RCT & $\begin{array}{l}\text { Ramipril, } n=4654 \\
\text { Placebo, } n=4652\end{array}$ & $\begin{array}{l}\text { MI, stroke and deat } \\
14.0^{\mathrm{a}} \\
17.8\end{array}$ & $\begin{array}{l}h \\
10.4^{a} \\
12.2\end{array}$ & $\begin{array}{l}\text { ACEi vs. placebo: RR } 0.84 \\
(0.75-0.95) \text { for mortality }\end{array}$ & $\begin{array}{l}\text { A landmark study on ACEi. Of total } \\
9297 \text { patients, } 25 \% \text { of them had } \\
\text { already undergone CABG. A mean fol- } \\
\text { low-up was } 5 \text { years. }\end{array}$ \\
\hline $\begin{array}{l}\text { IMAGINE } 49 \\
2008\end{array}$ & $\mathrm{RCT}$ & $\begin{array}{l}\text { Quinapril, } n=1280 \\
\text { Placebo, } n=1273\end{array}$ & $\begin{array}{l}\text { Composite results }^{d} \\
13.7 \\
12.2\end{array}$ & $\begin{array}{l}2 \\
2\end{array}$ & $\begin{array}{l}\text { ACEi vs. placebo: HR } 1.00 \\
(0.59-1.69) \text { for mortality }\end{array}$ & $\begin{array}{l}\text { Only included "low-risk" patients and } \\
\text { excluded diabetic patients; the doses of } \\
\text { quinapril may have been excessive. }\end{array}$ \\
\hline $\begin{array}{l}\text { Benedetto et } a l^{58} \\
2008\end{array}$ & $\begin{array}{l}\text { Retrospective } \\
\text { cohort }\end{array}$ & $\begin{array}{l}\text { ACEi, } n=281 \\
\text { No ACEi, } n=255\end{array}$ & $\begin{array}{l}\text { AKI } \\
6.4^{\mathrm{a}} \\
12.2\end{array}$ & $\begin{array}{l}2.8 \\
3.5\end{array}$ & $\begin{array}{l}\text { ACEi vs. without one: OR } \\
0.48(0.23-0.77) \text { for AKI }\end{array}$ & $\begin{array}{l}\text { Patients included had received } 2 \text { or } \\
\text { more weeks of ACEi until the day of } \\
\text { surgery and underwent isolated CABG. }\end{array}$ \\
\hline $\begin{array}{l}\text { Arora et al }{ }^{59} \\
2008\end{array}$ & $\begin{array}{l}\text { Retrospective } \\
\text { cohort }\end{array}$ & $\begin{array}{l}\text { RASi, } n=706 \\
\text { No RASi, } n=652\end{array}$ & $\begin{array}{l}\text { AKI } \\
43.4^{\mathrm{a}} \\
36.7\end{array}$ & NA & $\begin{array}{l}\text { RASi vs. without one: OR } \\
1.35 \text { (1.05-1.73) for AKI }\end{array}$ & $\begin{array}{l}\text { The patients on RASi were significantly } \\
\text { sicker (more with diabetes, hyperten- } \\
\text { sion, heart failure, obesity, etc.) than } \\
\text { without one. }\end{array}$ \\
\hline $\begin{array}{l}\text { Barodka et al }{ }^{60} \\
2009\end{array}$ & $\begin{array}{l}\text { Retrospective } \\
\text { cohort }\end{array}$ & $\begin{array}{l}\text { RASi, } n=122 \\
\text { No RASi, } n=224\end{array}$ & $\begin{array}{l}\text { AKI } \\
1.64^{\mathrm{a}} \\
7.59\end{array}$ & $\begin{array}{l}5.7 \\
4.0\end{array}$ & $\begin{array}{l}\text { RASi vs. without one: OR } \\
0.19(0.04-0.84) \text { for AKI }\end{array}$ & $\begin{array}{l}\text { All included patients were } \geqslant 65 \text { years } \\
\text { old and underwent } C A B G \text { or valve sur- } \\
\text { gery. The sample size lacked power to } \\
\text { reveal the difference for mortality. }\end{array}$ \\
\hline $\begin{array}{l}\text { Benedetto et } a l^{50} \\
2008\end{array}$ & $\begin{array}{l}\text { Retrospective } \\
\text { cohort }\end{array}$ & $\begin{array}{l}\text { ACEi, } n=245 \\
\text { No ACEi, } n=236\end{array}$ & $\begin{array}{l}\mathrm{MI} \\
2.0 \\
4.2\end{array}$ & NA & NA & $\begin{array}{l}\text { ACEi prior to surgery was found to } \\
\text { reduce postoperative cTnl release } \\
\text { significantly. }\end{array}$ \\
\hline & & & AKI & & & \\
\hline Miceli et $a l^{52}$ & $\begin{array}{l}\text { Retrospective } \\
\text { cohort }\end{array}$ & $\begin{array}{l}\text { ACEi, } n=3052 \text { No } \\
\text { ACEi, } n=3052\end{array}$ & $\begin{array}{l}7.1^{\mathrm{a}} \\
5.4\end{array}$ & $\begin{array}{l}1.3^{\mathrm{a}} \\
0.7\end{array}$ & $\begin{array}{l}\text { ACEi vs. without one: OR } \\
2.00(1.17-3.42) \text { for } \\
\text { mortality }\end{array}$ & $\begin{array}{l}\text { At baseline, the patients on ACEi were } \\
\text { markedly sicker (more with hyperten- } \\
\text { sion, diabetes, left main disease, pre- } \\
\text { vious MI and etc.) than without ACEi. }\end{array}$ \\
\hline
\end{tabular}

Abbreviations: ACEi, angiotensin-converting enzyme inhibitor; AKI, acute kidney injury; CABG, coronary artery bypass graft; Cl confidence interval; HR, hazard ratio; MI, myocardial infarction; NA, not available; OR, odd ratio; $\mathrm{PCl}$, percutaneous coronary intervention; RASi, renin-angiotensin system inhibitors; RCT, randomized clinical trial; RR, relative risk.

aWith significant difference vs. placebo, no ACEi or no RASi group, respectively $(P<0.05)$.

bIschemic events include death, revascularization, $\mathrm{MI}$, recurrence of angina pectoris, ischemic stroke and transient ischemic attack.

Ischemic events include death, revascularization, MI, recurrence of angina pectoris,
cTriple-composite outcomes include cardiac death, acute MI or clinical heart failure.

${ }^{d}$ Composite end points include cardiovascular death, resuscitated cardiac arrest, non-fatal MI, coronary revascularization, unstable angina or heart failure requiring hospitalization, documented angina and stroke. 
pectoris, ischemic stroke and transient ischemic attack in patients undergoing CABG. The patients $(n=149)$ were randomized to receive quinapril ( $40 \mathrm{mg} /$ day up to 1 year) beginning 4 weeks before CABG. The results showed that treatment with quinapril significantly reduced clinical ischemic events after CABG (4\% in quinapril patients vs. $15 \%$ in placebo patients; hazard ratio $0.23,95 \%$ CI $0.06-0.87, P=0.02$ ). In the Angiotensin-converting Enzyme Inhibition Post Revascularization (APRES) trial, Kjoller-Hansen et al. ${ }^{48}$ studied 159 patients (130 CABG, 29 PCI) with normal blood pressure and moderately depressed ejection fractions, who were randomly assigned to receive either ramipril or placebo shortly after invasive revascularization and subsequently followed up for a median of 33 months. The results showed that ramipril significantly reduced the incidence of the composite end point of cardiac death, AMI or clinical heart failure (risk reduction $58 \%$; $95 \%$ CI $7-80 \%, P=0.031$ ). Both the QUO VAIDS and the APRES studies are randomized trials but are limited by their small sample size ( $<160$ patients); thus, it is important not to make strong conclusions based on such studies. Instead, these studies indicate the need for larger confirmatory studies.

In 2008, Rouleau et al. ${ }^{49}$ found in the Ischemia Management with Accupril Post Bypass Graft via Inhibition of Angiotensin Converting Enzyme (IMAGINE) trial $(n=2553)$ that postoperative therapy with quinapril ( $40 \mathrm{mg} /$ day, started $<7$ days after surgery) did not improve clinical outcomes (cardiovascular events and death) up to 3 years after surgery in low-risk CABG patients. Instead, postoperative treatment with quinapril may have increased adverse events in the early postoperative period (hazard ratio $1.52,95 \%$ CI 1.03-2.26, $P=0.0356$ ). The IMAGINE trial is the largest randomized trial thus far in the field of ACE inhibitors in cardiac surgery. In contrast to the results from the QUO VAIDS and APRES trials, the IMAGINE trial indicated that ACE inhibitors may not benefit patients undergoing cardiac surgery but can instead have deleterious effects. Nevertheless, one limitation of this study is the inclusion of only 'low-risk' patients undergoing CABG. Another limitation is that the doses may have been excessive, as a significantly higher incidence of hypotension was found in patients receiving quinapril (12\%) vs. those receiving placebo $(5.5 \%$, $P<0.001)$. Finally, the ACE inhibitor used in that study was started acutely in the postoperative period, although it is known that the potential benefits of ACE inhibitors, especially their pleiotropic effects, occur over long periods of time.

With regard to observational studies, Benedetto et al. ${ }^{50}$ found in a retrospective study $(n=481)$ that ACE inhibitors before surgery confer added myocardial protection (reducing cardiac troponin release) in patients undergoing CABG. Further evidence supporting the beneficial effects of the ACE inhibitor ramipril in reducing/preventing cardiovascular events comes from the landmark Heart Outcomes Prevention Evaluation trial, which included 9297 patients with high risk of CVD. Of these patients, $26 \%$ had already undergone CABG. Compared with placebo, long-term treatment with ramipril significantly decreased the rates of MI, stroke and death (RR of $0.78,95 \%$ CI $0.70-0.86$, $P<0.01)^{34}$

Recently, two retrospective studies reported conflicting results. On the basis of 9129 patients undergoing elective or urgent CABG and/or valve surgery from January 1994 to December 2007 at Johns Hopkins University in the USA, Barodka et al. ${ }^{51}$ found that preoperative use of ACE inhibitors was independently associated with a significantly reduced risk of 30-day mortality (OR $0.72,95 \%$ CI 0.57-0.92, $P<0.007)$. In contrast, on the basis of the data of 10023 patients undergoing isolated CABG between April 1996 and May 2008 at Bristol Heart Institute of UK, Miceli et al..$^{52}$ reported that preoperative therapy with ACE inhibitors was associated with an increased risk of mortality (OR 2.00, 95\% CI 1.17-3.42, $P<0.03$ ). At this time, it is difficult to compare these two large observational studies, as the study by Barodka et al. has not been published as a fulllength paper. Of note, in the study by Miceli et $a l,{ }^{52}$ the patients on ACE inhibitors at baseline were obviously more sick than those not on ACE inhibitors, as shown clearly in higher rates of hypertension, diabetes, CHF, previous MI, left main disease and urgent and offpump CABG in the former group. It is likely that this was responsible for the increased mortality in patients with ACE inhibitors. Although the authors used the propensity score to match the patients in their trial, this score cannot overcome pitfalls, such as the initial selection bias and unmeasured confounders. It may also disregard individuals who cannot be matched, but an effect modification may exist. ${ }^{53}$

Thus far, very few reports have specifically addressed the potentially different effects of ACE inhibitors on patients undergoing on-pump or off-pump cardiac surgery. In a small $(n=80)$, non-randomized prospective study, Lee et al. reported that preoperative treatment with an ACE inhibitor significantly increased the amount of vasoconstrictor necessary to maintain the target mean arterial pressure during off-pump CABG. ${ }^{54}$ As often seen in non-randomized studies, the patients on preoperative ACE inhibitors in this study were in poorer health than controls, as evidenced by higher rates of diabetes and hypertension.

\section{ACE inhibitors in cardiac surgery associated-acute kidney injury}

Very few studies have been conducted specifically to investigate the effect of ACE inhibitors on acute kidney injury (AKI) or renal failure in cardiac surgery patients (Table 1). Several small randomized clinical trials $(n=14-40)$ provide evidence that perioperative ACE inhibitor therapy improved renal blood flow and/or function in patients undergoing cardiac surgery. ${ }^{55-57}$ In the postoperative intensive care unit, Wagner et al. investigated the effects of enalaprilat on cardiac and renal function in patients $(n=40)$ with a left ventricular ejection fraction $<35 \%$ following CABG. The results showed that intravenous enalaprilat increased creatinine clearance and decreased serum creatinine and urea. This therapy also improved cardiac and stroke volume indexes and lowered pulmonary vascular resistance. ${ }^{55}$

In observational studies, Benedetto et al. ${ }^{58}$ evaluated the effect of preoperative ACE inhibitors on acute kidney injury (AKI) in 536 patients undergoing CABG. They found that the incidence of acute kidney injury (AKI) was $6.4 \%$ in patients with ACE inhibitors but $12.2 \%$ in patients without ACE inhibitors (OR 0.48, 95\% CI $0.23-0.77 ; P<0.04)$. The results of this study are largely in line with the findings from our study (see below).

In contrast, Arora et al. $(2008)^{59}$ and Miceli et al. (2009) $)^{52}$ found in their retrospective studies that preoperative use of RAS inhibitors in cardiac surgery patients was associated with increased risk of postoperative renal dysfunction. However, the patients who were on RAS inhibitors compared with those not on RAS inhibitors showed significantly increased rates of history of diabetes, hypertension, CHF and obesity, which likely explains why the patients on RAS inhibitors had an increased incidence of postoperative acute kidney injury (AKI) in these two studies.

We also conducted a retrospective cohort study in a single institution to examine the effects of preoperative use of RAS inhibitors on postoperative renal failure in aging patients $(n=346)$ undergoing cardiac surgery. With multivariate logistic regression analysis, the results from our study showed that preoperative use of RAS inhibitors significantly and independently reduced the incidence of postoperative renal failure in aging patients undergoing cardiac surgery compared with those not taking RAS inhibitors preoperatively (1.6 vs. 7.6\%; OR 
$0.19,95 \%$ CI $0.04-0.84, P=0.029)$, indicating that ACE inhibitors may benefit a subgroup of patients, if not all patients, undergoing cardiac surgery. ${ }^{60}$

\section{Potential side effects and their controversies}

In the non-surgical setting, as described above, ACE inhibitors have been conclusively demonstrated to reduce the risk of cardiovascular death, MI and death in patients at risk for cardiovascular events but without heart failure. ${ }^{34,35}$ In the surgical setting, however, the use of ACE inhibitors has been intensely debated. A major issue in the debate is hypotension or 'vasoplegia', a potential side effect of the perioperative use of ACE inhibitors. The mechanism of vasoplegia is unclear and likely related to the pathological activation of several vasodilator mechanisms and resistance to vasopressors. ${ }^{61}$ Because of this concern, there seem to be quite a few $\operatorname{pros}^{62-66}$ and $\operatorname{cons}^{67-69}$ as to whether preoperative ACE inhibitors should be continued or withdrawn before cardiac surgery.

It may be beneficial to review briefly the following related randomized clinical trials while considering the potential side effects of preoperative use of ACE inhibitors:

(1) Dose titration is key for successful application of this class of medicine. Here, the history of ACE inhibitor development is elucidative. In the early 1990s, investigators started to examine the effects of ACE inhibitors in patients post-AMI. An early and disappointing result from the Cooperative New Scandinavian Enalapril Survival Study II (CONSENSUS II) in $1992^{70}$ was soon overshadowed by a series of clinical trials that demonstrated the remarkable survival benefits of ACE inhibitors in patients with AMI, especially after a careful titration of ACE inhibitors in the immediate postinfarction period was applied in these trials to avoid the development of hypotension. ${ }^{30-33}$ For example, in the study of the effects of lisinopril and transdermal glyceryl trinitrate, dosed singly and together, on 6-week mortality and ventricular function after AMI (GISSI-3 trial), ${ }^{30}$ patients with a systolic blood pressure of $120 \mathrm{~mm} \mathrm{Hg}$ or lower at randomization or in the first 3 days could be given a lower dose of lisinopril $(2.5 \mathrm{mg}$ ). If hypotension (systolic blood pressure $\leqslant 100 \mathrm{~mm} \mathrm{Hg}$ ) occurred at any time during the study, a maintenance dose of $5 \mathrm{mg}$ daily could be adopted. Temporary reductions to $2.5 \mathrm{mg}$ were also allowed. In severe hypotension (systolic blood pressure $<=90 \mathrm{~mm} \mathrm{Hg}$ ), lisinopril could be withdrawn.

(2) Although the HOPE trial ${ }^{34}$ did not specifically address the issue of ACE inhibitors in cardiac surgery patients, 26\% of the 9297 patients in the trial had already undergone a CABG. In these CABG patients, long-term use of the ACE inhibitor ramipril significantly reduced cardiovascular complications and death, which occurred when a low dose of ramipril was given (starting with $2.5 \mathrm{mg}$ per day to a full dose of $10 \mathrm{mg}$ per day). As a result, the mean reduction in blood pressure in the ramipril group was only $2-3 \mathrm{~mm} \mathrm{Hg}$, suggesting that the beneficial effects of ACE inhibitor therapy were largely due to the inhibition of tissue ACE-mediated processes, aside from the antihypertensive effects of this therapy, and this could be achieved without drug-induced hypotension or vasoplegia.

(3) Although the aim of the Perioperative Ischemic Evaluation Study (POISE) ${ }^{8}$ was to determine the effects of perioperative metoprolol on major cardiovascular events, the design of this study also helped the analysis of results from similar clinical studies on ACE inhibitors. The results of the POISE are mixed. There were significant reductions in the primary outcomes of cardiac death, non-fatal MI and cardiac arrest, but there was an increase in death (total mortality) and stroke. Other adverse effects included significant bradycardia and hypotension. In this study, patients $(n=8351)$ received an oral dose of $100 \mathrm{mg}$ control-release metoprolol or placebo $2-4 \mathrm{~h}$ before surgery and between 0 and $6 \mathrm{~h}$ after surgery. At $12 \mathrm{~h}$ after the first postoperative dose, patients started taking $200 \mathrm{mg}$ metoprolol or placebo daily and continued for 30 days after surgery. This treatment regimen and the fixed, higher dose and acute initiation metoprolol immediately before surgery are likely responsible for significant bradycardia and hypotension and, therefore, an increase in death and stroke. ${ }^{71}$ The results from the POISE highlight the risk of assuming that a prophylactic therapy with sympathetic block drugs, such as beta-blockers and ACE inhibitors, would have benefits without substantial harm.

Aside from hypotension, ACE inhibitor therapy usually improved renal function in patients with CVD and renal disease, but its use can be associated with a syndrome of 'functional renal insufficiency' and/ or hyperkalemia, which is most likely to occur when renal perfusion pressure levels cannot be sustained, (for example, hypotension, dehydration or renal artery disease).$^{72}$ These conditions should be avoided or rectified during ACE inhibitor therapy.

The aldosterone 'escape' or 'breakthrough' phenomenon has been observed during long-term ACE inhibitor treatment. The incidence of this phenomenon ranges from $10 \%$ over 6 months to $53 \%$ over 1 year. ${ }^{73}$ This could be the result of ACE gene polymorphisms that are involved in the modulation and adequacy of the neurohormonal response to long-term ACE inhibition. ${ }^{74}$ Aldosterone breakthrough may attenuate the myocardial protective effect of ACE inhibitors, ${ }^{75}$ and the additional inhibition of aldosterone may provide better myocardial protection than an ACE inhibitor alone.

\section{Current clinical use of ACE inhibitors}

Several large clinical trials have demonstrated that ACE inhibitors are remarkably safe and well tolerated by most patients, and the side effects are generally reversible after discontinuation of the medication. $^{30,34,35}$ During therapy with ACE inhibitors, mild, asymptomatic hypotension is an acceptable side effect, but the development of significant hypotension should be avoided in patients undergoing cardiac surgery.

Nevertheless, optimal type, dose, timing, duration, titration and potential side effects of perioperative use of ACE inhibitors remain to be investigated, especially hypotension/vasoplegia and its prognostic significance. At present, perioperative use of ACE inhibitors should be started long before the scheduled surgery and then titrated carefully to seek their beneficial effects while avoiding hypotension or vasoplegia.

\section{Summary}

Although tremendous progress has been made in the field of cardiac surgery over the past four decades, clinical preventive therapy research on the reduction of major complications associated with this type of surgery is sparse and inconclusive; yet the complications of cardiac procedures remain significant and costly. Meanwhile, multiple randomized clinical trials and meta-analyses have clearly demonstrated that long-term use of ACE inhibitors in the non-surgical setting provides end-organ protection and reduces mortality and morbidity, including cardiovascular and renal events in patients with CVD, AMI, diabetes and kidney diseases. However, thus far, the results of ACE inhibitor studies in the surgical setting, especially for cardiac surgery patients, remain uncertain, controversial and even contradictory. Therefore, 
on the basis of the evidence and limitations described above, well-designed clinical studies, including both retrospective (multicenters) and prospective (large randomized clinical trial) studies, conducted before potentially widespread use of ACE inhibitors may settle controversies, save considerable money and time and ultimately spare lives.

\section{CONFLICT OF INTEREST}

The authors declare no conflict of interest.

1 Brown PP, Kugelmass AD, Cohen DJ, Reynolds MR, Culler SD, Dee AD, Simon AW. The frequency and cost of complications associated with coronary artery bypass grafting surgery: results from the United States Medicare program. Ann Thorac Surg 2008; 85: 1980-1986.

2 Vaughan-Sarrazin MS, Hannan EL, Gormley CJ, Rosenthal GE. Mortality in Medicare beneficiaries following coronary artery bypass graft surgery in states with and without certificate of need regulation. JAMA 2002; 288: 1859-1866.

3 Alexander KP, Anstrom KJ, Muhlbaier LH, Grosswald RD, Smith PK, Jones RH, Peterson ED. Outcomes of cardiac surgery in patients $>$ or $=80$ years: results from the National Cardiovascular Network. J Am Coll Cardiol 2000; 35: 731-738.

4 Shroyer AL, Coombs LP, Peterson ED, Eiken MC, DeLong ER, Chen A, Ferguson Jr TB, Grover FL, Edwards FH. The society of thoracic surgeons: 30-day operative mortality and morbidity risk models. Ann Thorac Surg 2003; 75: 1856-1864

5 Mangano DT. Aspirin and mortality from coronary bypass surgery. N Eng/ J Med 2002, 347: 1309-1317.

6 Liakopoulos OJ, Choi YH, Haldenwang PL, Strauch J, Wittwer T, Dorge H, Stamm C, Wassmer G, Wahlers T. Impact of preoperative statin therapy on adverse postoperative outcomes in patients undergoing cardiac surgery: a meta-analysis of over 30000 patients. Eur Heart J 2008; 29: 1548-1559.

7 Ferguson Jr TB, Coombs LP, Peterson ED. Preoperative beta-blocker use and mortality and morbidity following CABG surgery in North America. JAMA 2002; 287: 2221-2227.

8 Devereaux PJ, Yang H, Yusuf S, Guyatt G, Leslie K, Villar JC, Xavier D, Chrolavicius S, Greenspan L, Pogue J, Pais P, Liu L, Xu S, Malaga G, Avezum A, Chan M, Montori VM, Jacka M, Choi P. Effects of extended-release metoprolol succinate in patients undergoing non-cardiac surgery (POISE trial): a randomised controlled trial. Lancet 2008; 371: 1839-1847.

9 Young EW, Diab A, Kirsh MM. Intravenous diltiazem and acute renal failure after cardiac operations. Ann Thorac Surg 1998; 65: 1316-1319.

10 Weightman WM, Gibbs NM, Sheminant MR, Whitford EG, Mahon BD, Newman MA. Drug therapy before coronary artery surgery: nitrates are independent predictors of mortality and beta-adrenergic blockers predict survival. Anesth Analg 1999; 88: 286-291.

11 Flesch M, Knipp S, Kessler G, Geissler HJ, Massoudy P, Wilhelm H, Philipp T, Erdmann E. ARTA: AT1-receptor blocker therapy in patients undergoing coronary artery bypass grafting. Clin Res Cardiol 2009; 98: 33-43.

12 Lazar HL. Role of angiotensin-converting enzyme inhibitors in the coronary artery bypass patient. Ann Thorac Surg 2005; 79: 1081-1089.

13 Weir MR. Effects of renin-angiotensin system inhibition on end-organ protection: can we do better? Clin Ther 2007; 29: 1803-1824.

14 Brown NJ, Agirbasli MA, Williams GH, Litchfield WR, Vaughan DE. Effect of activation and inhibition of the renin-angiotensin system on plasma PAI-1. Hypertension 1998; 32: 965-971.

15 Hornig B, Arakawa N, Drexler H. Effect of ACE inhibition on endothelial dysfunction in patients with chronic heart failure. Eur Heart J 1998; 19(Suppl G): G48-G53.

16 Spinale FG, Holzgrefe HH, Mukherjee R, Hird RB, Walker JD, Arnim-Barker A, Powell $J R$, Koster WH. Angiotensin-converting enzyme inhibition and the progression of congestive cardiomyopathy. Effects on left ventricular and myocyte structure and function. Circulation 1995; 92: 562-578.

17 Ali SM, Brown Jr EJ, Nallapati SR, Alhaddad IA. Early angiotensin converting enzyme inhibitor therapy after experimental myocardial infarction prevents left ventricular dilation by reducing infarct expansion: a possible mechanism of clinical benefits. Coron Artery Dis 1998; 9: 815-821.

18 Takai S, Yamamoto D, Jin D, Inagaki S, Yoshikawa K, Tanaka K, Miyazaki M. Inhibition of matrix metalloproteinase-9 activity by lisinopril after myocardial infarction in hamsters. Eur J Pharmacol 2007; 568: 231-233.

19 Lindsey ML, Gannon J, Aikawa M, Schoen FJ, Rabkin E, Lopresti-Morrow L, Crawford J, Black S, Libby P, Mitchell PG, Lee RT. Selective matrix metalloproteinase inhibition reduces left ventricular remodeling but does not inhibit angiogenesis after myocardial infarction. Circulation 2002; 105: 753-758.

$20 \mathrm{Klahr}$ S, Ishidoya S, Morrissey J. Role of angiotensin II in the tubulointerstitial fibrosis of obstructive nephropathy. Am J Kidney Dis 1995; 26: 141-146.

21 Morrissey JJ, Klahr S. Differential effects of ACE and AT1 receptor inhibition on chemoattractant and adhesion molecule synthesis. Am J Physiol 1998; 274: F580-F586.
22 Wu LL, Cox A, Roe CJ, Dziadek M, Cooper ME, Gilbert RE. Transforming growth factor beta 1 and renal injury following subtotal nephrectomy in the rat: role of the renin-angiotensin system. Kidney Int 1997; 51: 1553-1567.

23 Thomas SE, Andoh TF, Pichler RH, Shankland SJ, Couser WG, Bennett WM, Johnson RJ. Accelerated apoptosis characterizes cyclosporine-associated interstitial fibrosis. Kidney Int 1998; 53: 897-908.

24 Gironacci MM, Valera MS, Yujnovsky I, Peña C. Angiotensin-(1-7) inhibitory mechanism of norepinephrine release in hypertensive rats. Hypertension 2004; 44: 783-787.

25 Lu J, Zhang Y, Shi J. Effects of intracerebroventricular infusion of angiotensin-(1-7) on bradykinin formation and the kinin receptor expression after focal cerebral ischemiareperfusion in rats. Brain Res 2008; 1219: 127-135.

26 Saxena PR. Interaction between the renin-angiotensin-aldosterone and sympathetic nervous systems. J Cardiovasc Pharmacol 1992; 19(Suppl 6): S80-S88.

27 A placebo-controlled trial of captopril in refractory chronic congestive heart failure Captopril Multicenter Research Group. J Am Coll Cardiol 1983; 2: 755-763.

28 Effects of enalapril on mortality in severe congestive heart failure Results of the Cooperative North Scandinavian Enalapril Survival Study (CONSENSUS). The CONSENSUS Trial Study Group. N Engl J Med 1987; 316: 1429-1435.

29 Effect of enalapril on survival in patients with reduced left ventricular ejection fractions congestive heart failure The SOLVD Investigators. N Engl J Med 1991; 325: 293-302.

30 GISSI-3: effects of lisinopril transdermal glyceryl trinitrate singly together on 6-week mortality ventricular function after acute myocardial infarction Gruppo Italiano per lo Studio della Sopravvivenza nell'infarto Miocardico. Lancet 1994; 343: 1115-1122.

31 ISIS-4: a randomised factorial trial assessing early oral captopril oral mononitrate and intravenous magnesium sulphate in 58050 patients with suspected acute myocardial infarction ISIS-4 (Fourth International Study of Infarct Survival) Collaborative Group. Lancet 1995; 345: 669-685.

32 Ambrosioni E, Borghi C, Magnani B. The effect of the angiotensin-converting-enzyme inhibitor zofenopril on mortality and morbidity after anterior myocardial infarction. The Survival of Myocardial Infarction Long-Term Evaluation (SMILE) Study Investigators. N Engl J Med 1995; 332: 80-85.

33 Pfeffer MA, Braunwald E, Moye LA, Basta L, Brown Jr EJ, Cuddy TE, Davis BR, Geltman EM, Goldman S, Flaker GC. Effect of captopril on mortality and morbidity in patients with left ventricular dysfunction after myocardial infarction. Results of the survival and ventricular enlargement trial. The SAVE Investigators. N Engl J Med 1992; 327: 669-677.

34 Yusuf S, Sleight P, Pogue J, Bosch J, Davies R, Dagenais G. Effects of an angiotensinconverting-enzyme inhibitor, ramipril, on cardiovascular events in high-risk patients. The Heart Outcomes Prevention Evaluation Study Investigators. N Engl J Med 2000; 342: 145-153.

35 Fox KM. Efficacy of perindopril in reduction of cardiovascular events among patients with stable coronary artery disease: randomised, double-blind, placebo-controlled, multicentre trial (the EUROPA study). Lancet 2003; 362: 782-788.

36 Turnbull F, Neal B, Pfeffer M, Kostis J, Algert C, Woodward M, Chalmers J, Zanchetti A, MacMahon S. Blood pressure-dependent and independent effects of agents that inhibit the renin-angiotensin system. $J$ Hypertens 2007; 25: 951-958.

37 Danchin N, Cucherat M, Thuillez C, Durand E, Kadri Z, Steg PG. Angiotensinconverting enzyme inhibitors in patients with coronary artery disease and absence of heart failure or left ventricular systolic dysfunction: an overview of long-term randomized controlled trials. Arch Intern Med 2006; 166: 787-796.

38 Dagenais GR, Pogue J, Fox K, Simoons ML, Yusuf S. Angiotensin-converting-enzyme inhibitors in stable vascular disease without left ventricular systolic dysfunction or heart failure: a combined analysis of three trials. Lancet 2006; 368: 581-588.

39 Lopez-Sendon J, Swedberg K, McMurray J, Tamargo J, Maggioni AP, Dargie H, Tendera M, Waagstein F, Kjekshus J, Lechat P, Torp-Pedersen C. Expert consensus document on angiotensin converting enzyme inhibitors in cardiovascular disease. The Task Force on ACE-inhibitors of the European Society of Cardiology. Eur Heart J 2004; 25: 1454-1470.

40 Randomised placebo-controlled trial of effect of ramipril on decline in glomerular filtration rate and risk of terminal renal failure in proteinuric non-diabetic nephropathy The GISEN Group (Gruppo Italiano di Studi Epidemiologici in Nefrologia). Lancet 1997; 349: 1857-1863.

41 Efficacy of atenolol captopril in reducing risk of macrovascular and microvascular complications in type 2 diabetes: UKPDS 39 UK Prospective Diabetes Study Group. BMJ 1998; 317: 713-720.

42 Effects of ramipril on cardiovascular microvascular outcomes in people with diabetes mellitus: results of the HOPE study and MICRO-HOPE substudy Heart Outcomes Prevention Evaluation Study Investigators. Lancet 2000; 355: 253-259.

43 Brenner BM, Cooper ME, de Zeeuw D, Keane WF, Mitch WE, Parving HH, Remuzzi G, Snapinn SM, Zhang Z, Shahinfar S. Effects of losartan on renal and cardiovascular outcomes in patients with type 2 diabetes and nephropathy. N Eng/ J Med 2001; 345: 861-869.

44 Ruggenenti P, Fassi A, llieva AP, Bruno S, Iliev IP, Brusegan V, Rubis N, Gherardi G, Arnoldi F, Ganeva M, Ene-lordache B, Gaspari F, Perna A, Bossi A, Trevisan R, Dodesini AR, Remuzzi G. Preventing microalbuminuria in type 2 diabetes. N Engl J Med 2004; 351: 1941-1951.

45 Rady MY, Ryan T. The effects of preoperative therapy with angiotensin-converting enzyme inhibitors on clinical outcome after cardiovascular surgery. Chest 1998; 114: 487-494.

46 Weightman WM, Gibbs NM, Sheminant MR, Whitford EG, Mahon BD, Newman MA. Drug therapy before coronary artery surgery: nitrates are independent predictors of mortality and beta-adrenergic blockers predict survival. Anesth Analg 1999; 88: 286-291. 
47 Oosterga M, Voors AA, Pinto YM, Buikema H, Grandjean JG, Kingma JH, Crijns HJ, van Gilst WH. Effects of quinapril on clinical outcome after coronary artery bypass grafting (The QUO VADIS Study). QUinapril on Vascular Ace and Determinants of Ischemia. Am J Cardiol 2001; 87: 542-546.

48 Kjoller-Hansen L, Steffensen R, Grande P. The Angiotensin-converting Enzyme Inhibition Post Revascularization Study (APRES). J Am Coll Cardiol 2000; 35: 881-888.

49 Rouleau JL, Warnica WJ, Baillot R, Block PJ, Chocron S, Johnstone D, Myers MG, Calciu CD, Dalle-Ave S, Martineau P, Mormont C, van Gilst WH. Effects of angiotensinconverting enzyme inhibition in low-risk patients early after coronary artery bypass surgery. Circulation 2008; 117: 24-31.

50 Benedetto U, Melina G, Capuano F, Comito C, Bianchini R, Simon C, Refice S, Angeloni $\mathrm{E}$, Sinatra R. Preoperative angiotensin-converting enzyme inhibitors protect myocardium from ischemia during coronary artery bypass graft surgery. J Cardiovasc Med (Hagerstown) 2008; 9: 1098-1103.

51 Barodka V, Hogue CW, Nyhan D, Shah A, Pustavoitau A. The Role of preoperative medications on mortality after cardiac surgery. http://www.asaabstracts.com/strands/ asaabstracts/search.htm; jsessionid=13F91F1D29CC98F6FF6EDE46EB8FDDC3, Accessible on December 21. 2009.

52 Miceli A, Capoun R, Fino C, Narayan P, Bryan AJ, Angelini GD, Caputo M. Effects of angiotensin-converting enzyme inhibitor therapy on clinical outcome in patients undergoing coronary artery bypass grafting. J Am Coll Cardiol 2009; 54: 1778-1784.

53 Winkelmayer WC, Kurth T. Propensity scores: help or hype? Nephrol Dial Transplant 2004; 19: 1671-1673.

54 Lee YK, Na SW, Kwak YL, Nam SB. Effect of pre-operative angiotensin-converting enzyme inhibitors on haemodynamic parameters and vasoconstrictor requirements in patients undergoing off-pump coronary artery bypass surgery. J Int Med Res 2005; 33: 693-702.

55 Wagner F, Yeter R, Bisson S, Siniawski H, Hetzer R. Beneficial hemodynamic and renal effects of intravenous enalaprilat following coronary artery bypass surgery complicated by left ventricular dysfunction. Crit Care Med 2003; 31: 1421-1428.

56 Ryckwaert F, Colson P, Ribstein J, Boccara G, Guillon G. Haemodynamic and renal effects of intravenous enalaprilat during coronary artery bypass graft surgery in patients with ischaemic heart dysfunction. Br J Anaesth 2001; 86: 169-175.

57 Colson P, Ribstein J, Mimran A, Grolleau D, Chaptal PA, Roquefeuil B. Effect of angiotensin converting enzyme inhibition on blood pressure and renal function during open heart surgery. Anesthesiology 1990; 72: 23-27.

58 Benedetto U, Sciarretta S, Roscitano A, Fiorani B, Refice S, Angeloni E, Sinatra R. Preoperative Angiotensin-converting enzyme inhibitors and acute kidney injury after coronary artery bypass grafting. Ann Thorac Surg 2008; 86: 1160-1165.

59 Arora P, Rajagopalam S, Ranjan R, Kolli H, Singh M, Venuto R, Lohr J. Preoperative use of angiotensin-converting enzyme inhibitors/angiotensin receptor blockers is associated with increased risk for acute kidney injury after cardiovascular surgery. Clin J Am Soc Nephrol 2008; 3: 1266-1273.

60 Barodka V, Silvestry S, Zhao N, Jiao X, Whellan DJ, Diehl J, Sun JZ. Preoperative rennin-angiotensin system inhibitors protect renal function in aging patients undergoing cardiac surgery. J Surg Res (e-pub ahead of print 4 December 2009).
61 Levin MA, Lin HM, Castillo JG, Adams DH, Reich DL, Fischer GW. Early on-cardiopulmonary bypass hypotension and other factors associated with vasoplegic syndrome. Circulation 2009; 120: 1664-1671.

62 Licker M, Neidhart P, Lustenberger S, Valloton MB, Kalonji T, Fathi M, Morel DR. Long-term angiotensin-converting enzyme inhibitor treatment attenuates adrenergic responsiveness without altering hemodynamic control in patients undergoing cardiac surgery. Anesthesiology 1996; 84: 789-800.

63 Boldt J, Schindler E, Harter K, Gorlach G, Hempelmann G. Influence of intravenous administration of angiotensin-converting enzyme inhibitor enalaprilat on cardiovascular mediators in cardiac surgery patients. Anesth Analg 1995; 80: 480-485.

64 Heropoulos M, Schieren H, Seltzer JL, Bartkowski RR, Lessin J, Torjman M, Moody C, Goldberg ME. Intraoperative hemodynamic, renin, and catecholamine responses after prophylactic and intraoperative administration of intravenous enalaprilat. Anesth Analg 1995; 80: 583-590.

65 Bottcher M, Behrens JK, Moller EA, Christensen JH, Andreasen F. ACE inhibitor premedication attenuates sympathetic responses during surgery. Br J Anaesth 1994; 72: 633-637.

66 Tamayo E, Di Stefano S, Carassiti M, Florez S, Carrascal Y, Agro F. Evaluation of the withdrawal of ACE inhibitors in coronary artery surgery. Clin Ter 2004; 155: 171-174.

67 Raja SG, Fida N. Should angiotensin converting enzyme inhibitors/angiotensin II receptor antagonists be omitted before cardiac surgery to avoid postoperative vasodilation? Interact Cardiovasc Thorac Surg 2008; 7: 470-475.

68 Ryckwaert F, Colson P. Hemodynamic effects of anesthesia in patients with ischemic heart failure chronically treated with angiotensin-converting enzyme inhibitors. Anesth Analg 1997; 84: 945-949.

69 Mirenda JV, Grissom TE. Anesthetic implications of the renin-angiotensin system and angiotensin-converting enzyme inhibitors. Anesth Analg 1991; 72: 667-683.

70 Swedberg K, Held P, Kjekshus J, Rasmussen K, Ryden L, Wedel H. Effects of the early administration of enalapril on mortality in patients with acute myocardial infarction Results of the Cooperative New Scandinavian Enalapril Survival Study II (CONSENSUS II). N Engl J Med 1992; 327: 678-684.

71 Fleisher LA, Poldermans D. Perioperative beta blockade: where do we go from here? Lancet 2008; 371: 1813-1814.

72 Schoolwerth AC, Sica DA, Ballermann BJ, Wilcox CS. Renal considerations in angiotensin converting enzyme inhibitor therapy: a statement for healthcare professionals from the Council on the Kidney in Cardiovascular Disease and the Council for High Blood Pressure Research of the American Heart Association. Circulation 2001; 104: 1985-1991.

73 Bomback AS, Klemmer PJ. The incidence and implications of aldosterone breakthrough. Nat Clin Pract Nephrol 2007; 3: 486-492.

74 Athyros VG, Mikhailidis DP, Kakafika Al, Tziomalos K, Karagiannis A. Angiotensin II reactivation and aldosterone escape phenomena in renin-angiotensin-aldosterone system blockade: is oral renin inhibition the solution? Expert Opin Pharmacother 2007; 8: 529-535.

75 Tanabe A, Naruse M, Hara Y, Sato A, Tsuchiya K, Nishikawa T, Imaki T, Takano K. Aldosterone antagonist facilitates the cardioprotective effects of angiotensin receptor blockers in hypertensive rats. J Hypertens 2004; 22: 1017-1023. 